Ирина Антанасиевич

Белградский университет

Филологический факультет

Кафедра славистики

antiira@mail.ru
УДК 821.161.1-2.09

https://doi.org/10.18485/slavistika.2020.24.1.6

Оригинални научни рад примљено 11.02.2020.

прихваћено за штампу 21.05.2020.

\title{
ПЬЕСА ДУШАНА С. НИКОЛАЕВИЧА «ВОЛГА, ВОЛГА!» В КОНТЕКСТЕ ДИСКУССИЙ О РУССКОЙ ЭМИГРАЦИИ
}

Статья рассматривает ту часть творческого наследия писателя Душана С. Николаевича, которая касается творчества Достоевского. В статье даётся обзор его статей в сербской периодике, которые вызывали большой интерес у читателей и анализ пьесы «Волга, Волга!» (1927). Анализ этой части творчества Душана С. Николаевича даёт нам возможность определить, как сербское общество относилась к русским эмигрантам и почему оно своё восприятие России и русских беженцев на Балканах пропускало через призму идей, заложенных в творчестве Достоевского.

Ключевые слова: русская эмиграция, Достоевский, Душан С. Николаевич, «Волга, Волга!»

This scientific article examines that part of the creative heritage of the writer Dusan S. Nikolaevich, which concerns the work of Dostoevsky. The article gives an overview of his articles in the Serbian periodical, which aroused great interest among readers and analysis plays "Volga, Volga!" (1927). Analysis of this part of the work of Dusan S. Nikolaevich gives us the opportunity to determine how Serbian society treated Russian emigrants and why it perceived its perception of Russia and Russian refugees in the Balkans through the prism of ideas embedded in the work of Dostoevsky.

Keywords: Russian emigration, Dostoevsky, Dusan S. Nikolayevich, "Volga, Volga!".

\section{Посвящуается светлой памяти коллеги Бобана Чурича}

Дискуссии о русских беженцах в сербской прессе в период между двух войн оказались непосредственным образом связаны с Достоевским, причём связаны как с рецепцией его творчества, так и с анализом его убеждений. В дискуссиях того времени анализ творчества Достоевского активно включал и споры о русских эмигрантах: о природе эмиграции, её механизме, её влиянии на местное общество, культуру и пр.

Сербский читатель Достоевского, столкнувшись с русской эмиграцией, т.е. с иной культурологической моделью, находящейся в процессе бытовой межкультурной трансформации, связанной с интеграцией в чуждую культурную среду, конечно же, пытался выработать, в свою очередь, свою модель понимания, которая для сербов была несколько болезненной, поскольку в чем-то нарушала или разрушала бытующие веками представления о России и русских. Отсюда возникало иногда неприятие некоторых сторон жизни русской эмиграции, в которых также винили русскую революцию, испортившую «настоящих русских». Мир бесов, мир униженных и оскорбленных, мир бедных людей, описанный Достоевском оказался рядом и это пугало.

Дискуссии, возникшие в прессе апеллировали к творчеству Достоевского, находя в его произведениях как доказательства того, что Россия, исполнившись 
гордыни, должна умереть, так и того, что её смерть лишь временна и русские как мудрые и старшие братья ещё могут, несмотря на все невзгоды, быть примером для славянского мира.

О Достоевском писали многие сербские исследователи тех лет: М. Джурич, Ю. Попович, В. Вуйич. М. Радойчич, А. Илич, В. Дворникович и др. (Успенски 2013). Но наша статья посвящена работам Душана Николаевича, публиковавшем газетные тексты о Достоевском, которые печатались в сербской прессе межвоенного периода, а отдельное внимание мы обратим на его пьесу «Волга, Волга», в подзаголовке которой стояло: Драма из жизни русских беженцев.

Душан Николаевич (1885-1961) или Душан С. Николаевич - сербский журналист, литературовед, драматург. С - это отсылка к отцу Светомиру Николаевичу (1844-1922), известному филологу, академику Сербской королевской академии и политику, одному из основателей Сербской радикальной партии. Светомир Николаевич в своей карьере был сначала градоначальником Белграда, затем министром внутренних дел, а короткое время, с 3 апреля по 27 октября, премьер-министром Сербии (Јордановић и др. 2005). Его сын Душан Николаевич получил юридическое образование (учился в Мюнхене, Лейпциге и Вене), а по возвращении из -за границы стал независимым журналистом, полемические статьи которого охотно печатались в газетной периодике того времени. Также Душан Николаевич был основателем и председателем Сербского объединения журналистов (до 1921), а позже возглавил Югославское объединение журналистов. Интересно, что когда Душан Николаевич был председателем Объединения, его секретарём был Моше Пияде, уже к тому времени член коммунистической партии Югославии и ближайший соратник Йосипа Броза Тито, хотя сам Душан Николаевич последовательно придерживался крайне правых взглядов о чем свидетельствуют его публицистические тексты и интервью. 


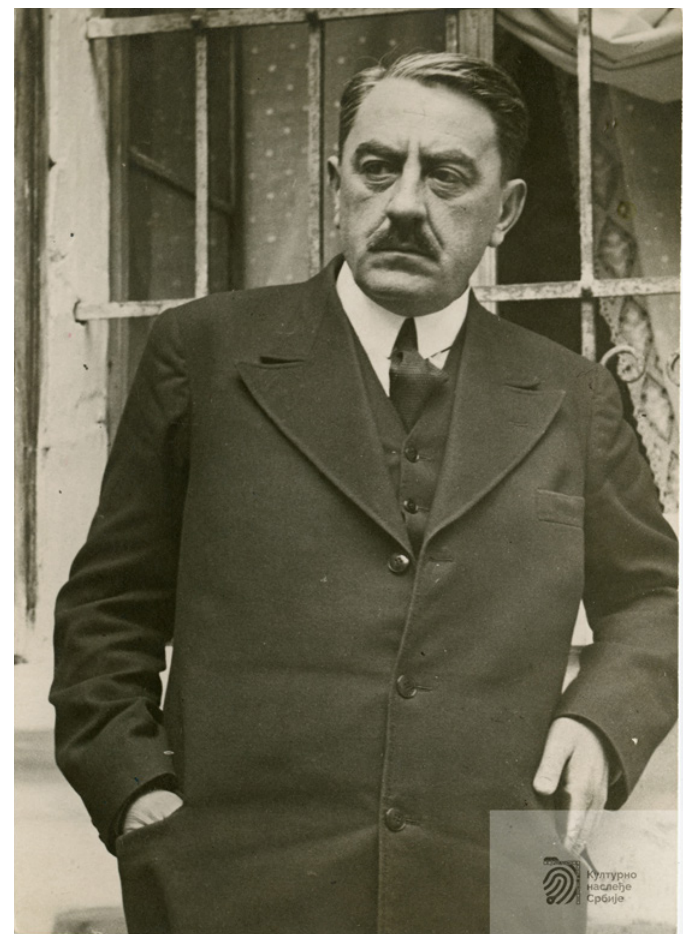

Фотография Душана Николаевича конца 30-х годов, Архив Музея театрального искусства в Белграде, ИД: 205464, Инвентарный номер: 13016-3

Душан Николаевич прежде всего известен как критик и драматург. Хотя до недавнего времени его творчество исследовалось мало и поверхностно, и только в последние годы мы видим, что это имя возвращается в круг исследователей сербской литературы XX века: анализом его драматургического наследия занимается А. Марич (Марић 2012; Марић 2013), которая опирается прежде всего на на работы М. Богановича (Богдановић 1973) и Р. Вучковича (Vučković 1982).

Критическое же наследие Николаевича ещё ожидает своего исследователя, а пока же отмечается, что «Николаевич находился... в открытом литературно-критическом столкновении с Йованом Скерличем и Богданом Поповичем (ведущими критиками начала XX века - примечания и перевод автора статьи), а в своих публицистических текстах дерзко создавал экзотические теории и формировал литературно неверные изначально суждения...» (Марић 2012) Действительно, критические статьи, которые Николаевич публиковал в сербской прессе далеки от привычных критических заметок или обзоров, а являются публицистическими очерками, где литература используется в качестве аргумента, при помощи которого автор высказывает своё мнение об актуальных общественно-политических и культурных вопросах. Печатались тексты Душана Николаевича именно поэтому не на страницах специализированных изданий, которые занимались критическим обзорами, а в газетах и представляли собой обширные авторские 
колонки, имеющие мало общего с собственно литературной (или театральной) критикой.

Исследователи считают, что стиль этих текстов был показательно эпатажным, чем объясняется их несколько пренебрежительное отношение к Николаевичу: например, Велибор Глигорич называл его «журналистом театрального стиля» (Gligorić 1977). Но сам анализ выбора стиля, на которое сделал упор автор, анализ тем и вопросов, которые он поднимал на страницах прессы, может быть очень интересен, особенно если сделать попытку рассмотреть его не в рамках литературных споров того времени, а как общественную реакцию на актуальные проблемы.

Для нас особый интерес вызывает серия текстов, в которых Душан Николаевич, прибегая к анализу творчества Достоевского, не только даёт оценку событиям «русской революции», как называет он Октябрьскую революцию, но и через фильтр этого суждения оценивает современную Европу, делая политические прогнозы и выдвигая идеологические макеты дальнейшего взаимодействия Балкан как с Советской Россией, так и с Европой. Нужно учитывать, что все это публикуется на страницах газет, причём для этих текстов выделяется довольно значительное газетное пространство и публикуются его статьи рядом с актуальными рассуждениями или фельетонами на злобу дня, что свидетельствует о том, что статьи эти были востребованы. Данные тексты написаны весьма простым языком, хотя страсть и убеждение автора в собственной правоте заразительна.

Исследователь В. Глигорич, пытаясь понять феномен популярности Николаевича, писал: „Госп. Николаевич индивидуалист, последний наш романтик, обладающий всеми особенностями типично балканского интеллигента. Он в европейскую философию <..> вступил самоучкой с «керосиновой лампой» квазинаучных методов в руках». И далее: «Госп. Николаевич любит философские страшилки, любит ввести читателя в недоумение, любит попугать и эпатировать. Обычная публика, которая мало что знает о философии, когда встречается неожиданно с госп. Николаевичем, который начинает им вещать о чуждых им темах, вынося свои претенциозные суждения, видит в нем того, единственного, который может взойти на духовные Гималаи. И он для их удовольствия и совершает восхождения на эти бумажные Гималаи, раздавая пощечины европейским философам и теологам и презирая преданную ему интеллектуальную паству“ (Gligorić 1977). С суровостью оценки В. Глигорича можно поспорить, но не учитывать того, что тексты Душана Николаевича были очень популярны, мы не имеем права. Может потому, что так или иначе, он успешно поднимал и популяризировал некоторые темы, и в этом также его заслуга. Отстаивая в политике последовательную позицию национального толка, он и как критик, оставался ей верен. Что, собственно, и чувствуется в его текстах. Кроме того, он был чутким слушателем и хорошо знал, что волнует и интересует публику. Поэтому, рассуждая о философии и литературе, обсуждая театральное представление или художественное произведение, он все свои суждения делает прикладными и применяет на актуальную политически-общественную ситуацию, соединяя прихотливо «мистику восточных философов с метафизическими идеями русской эмигрантской мысли и опираясь на национальную мифическую традицию» (Вучковић 1982). 
В серию текстов Душана Николаевича, связанных с именем Достоевского, необходимо в обязательном порядке включить три текста - это статья «Три момента творчества Достоевского», который печатался в газете «Правда» от 17.12.1933 (здесь и далее газеты цитируются по текстам, найденным нами в фонде Университетской библиотеки им. Светозара Марковича в Белграде) и который представляет собой перепечатку лекции Душана Николаевича (он читал её в Институте Коларац 14 декабря 1933 года.)

В статье, которая занимает большую часть 11-ой страницы газеты выделены три ключевых, по мнению автора, момента, связанных с поэтикой Достоевского:

1. Достоевский как внутренний портретист: здесь автор, опираясь на статьи Д. Мережковского (вероятнее всего имеется ввиду исследование Мережковского «Л. Толстой и Достоевский», которое написано в 1903 году, а в 1914 вошло в Полное собрание сочинений Д.С. Мережковского) и С. Цвейга (книга литературных портретов Три мастера. Бальзак - Диккенс - Достоевский (Drei Meister. Balzac - Dickens - Dostojewski) первая публикация 1920 года) доказывает тезис о приоритете детали над портретным изображением в творчестве Достоевского;

2. Достоевский и Шекспир: где Шекспир, по мнению автора, представляет идейную оппозицию Достоевскому, поскольку являет собой «простейшую физиологию зла, которое в настоящее время вылилось в английский спиритизм - феномен вульгарной материализации неба», в то время как Достоевский показывает динамику человеческой трагедии так, что придаёт ей глубину, свойственную истинному трагизму;

3. Достоевский и Фрейд: в которой автор подчёркивает разницу между фрерйдизмом и психологизмом Достоевского, который не стремится описать преступника и определить параметры характера преступной личности, а описывает обычных людей, чья личность синтетична и многогранна и которые способны как спускаться на самое дно пороков, так и возвышаться до духовных идеалов.

Как мы видим, в данной статье, нет особой эпатажности: она лишь представляет тезисный пересказ лекции, причём неприязнь Шекспира и критика фрейдизма - это привычные для текстов Душана Николаевича постулаты. Другой его, более острый, текст газета «Правда» публикует в нескольких номерах, начиная с 30 ноября 1933 года. Этот текст под названием «Еврейство и христианство» также упоминает психологию Достоевского как некий глубинный славянский феномен. Это не означает, что Николаевич Достоевского считает образцом творца и идеализирует. Напротив, в этом, а и в других своих текстах он пользуется им как оселком, посредством которого подчёркиваются и вверяются чужие ошибки. Слабости Достоевского, подчерчивает Душан Николаевич - это слабости христианского мира, а славянство ещё сильнее усиливает эти слабости.

Следующую большую статью Душана Николаевича - третий его текст о писателе - под названием «Достоевский и Ницше», печатает также газета «Правда» в нескольких номерах, начиная с 22.11.1934 года. В ней Душан Николаевич, споря с Эптоном Биллом Синклером и Стефаном Цвейгом, углубляет свою теорию о Достоевском как славянском христианском мыслителе, который противостоит физиологизму и механицизму западной философии. Здесь 
Достоевский - этот «фанатичный христианин», сталкивается с Ницще, которого автор представляет «фанатичным анти-христианином».

Впрочем, в заключении он, подчёркивая разницу между Ницще и Достоевским, обвинит и одного и другого в „садистском удовольствии, с которым они не дают человечеству ни одного солнечного лучика надежды».

Но творчество Достоевского для Николаевича не просто удобная возможность столкнуть две художественные концепции или две философские системы. Это ещё и попытка столкнуть меж собой две идеологии - европейскую и русскую. И, более того, посредством диалога с Достоевским Николаевич пытается примирить «беженскую Россию» и «ленинскую Россию», а также понять природу русской революции. Делает он это в пьесе «Волга, Волга», которая опубликована в 1927 году (Николајевић 1927).

Это третья пьеса автора (пьесы Душана Николаевича: Многая лета (1925), Пароль (1926), Волга, Волга!... (1927), Переступая через мёртвых (1931), Вечный траур (1932), Клевета (1938), Иван Градоевич (1940)), которая, в отличие от остальных, не сразу обрела своё сценическое воплощение из-за скандального идеологического посыла, заключённого в ней. Главными героями этой пьесы автор сделал Ленина (в первом издании в одной части тиража вместо Ленин написано Владимир Ильич Ульянов, а в другой части тиража - Антидостоевский), и Достоевского, чьи взгляды являются оселком, на котором проверяется то, что делает русского человека таким сильным и таким слабым. Сравнивая Европу и Россию, Душан Николевич отдаёт приоритет России. Он считает, что Европа больна («вся Европа усеяна статуями мёртвого Христа»), больна настолько, что даже революцию выносить в своих недрах не в состоянии, а Россия, переболеет детской ветрянкой своей революции и, соединив христианина Достоевского и Ленина-Антидостоевского («он антихрист, конечно, но он русский! Русский, и этим все сказано») под знаком общей национальной идеи, пойдёт вперёд. «И «разольётся Волга», и потопит все храмы европейские. И не прольётся ни слезинки, когда будет умирать Европа!» - так говорит Достоевский, всходя на крест и умирая в драме за ленинскую идею всемирной революции, которая должна быть не социалистической, по мнению автора, а революцией национальной идеи. Настоящей Русской революцией. 


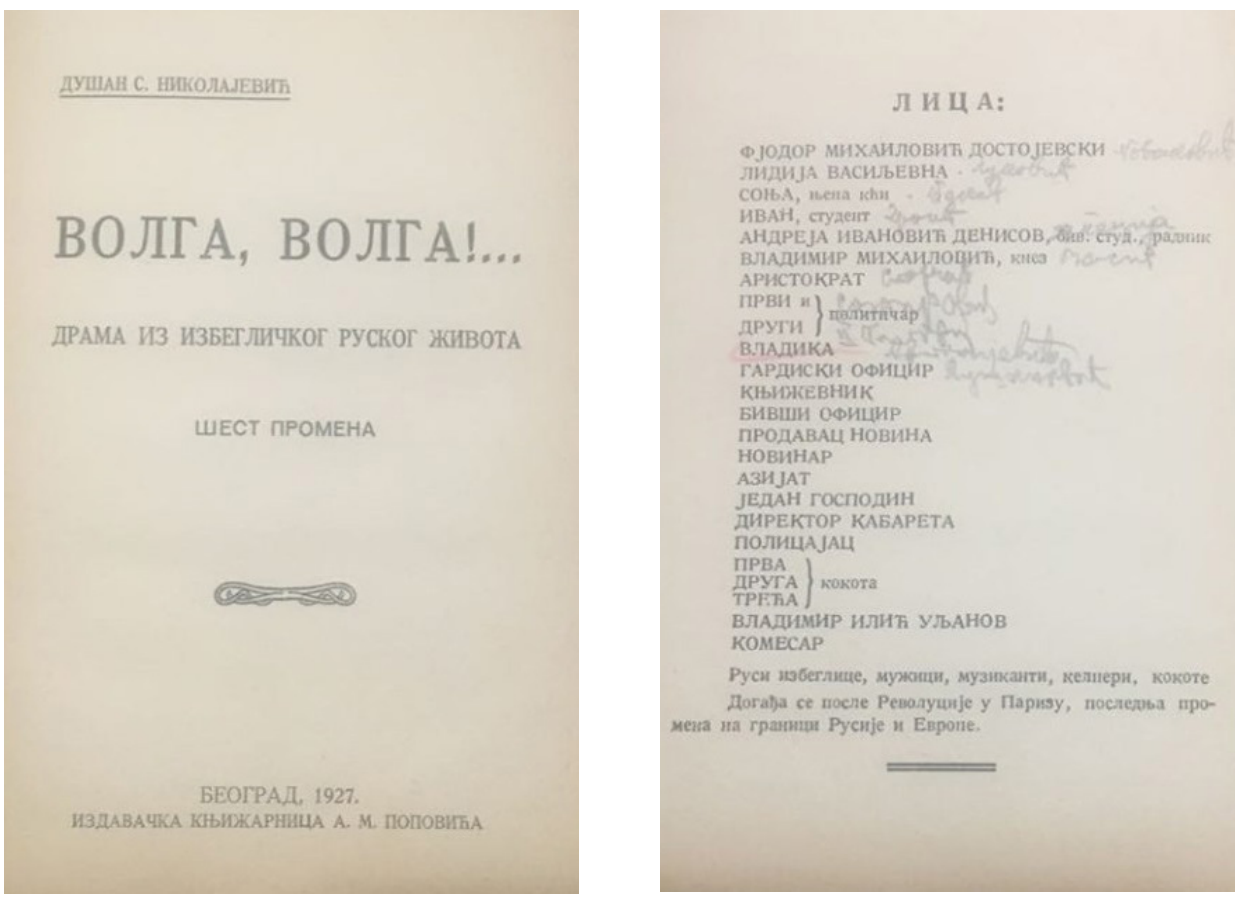

Обложка и действующие лица пьесы «Волга, Волга!»

Наличие национальной идеи - это то, что необходимо России. В этом ее спасение и способ примирения двух Россий - «ленинской» и «беженской», которые, отказавшись от опасных идей социалистического интернационализма и либерального европеизма, сформируют единую великую и сильную страну. Подобные идеи он и позже выскажет в театральной рецензии в газете «Время» от 27 октября 1928 года на пьесу Дмитрия Мережковского «Царевич Алексей». Данная рецензия - не только анализ пьесы Мережковского, но и анализ Мережковского «как русского беженца, который преданно служит культу Наполеона, что является характеристикой не только его личной, но и части эмигрантской России». В этой статье, Николаевич рассуждает о пьесе, «наполеонолюбии» части русской эмиграции, русской мечте о «цезаре».

В этой статье мы опять же видим тенденцию рассмотреть русскую эмиграцию через призму того литературного наследия, которое она оставила и желание понять русскую революцию: «Русская революция дала истории солнце. Кровавое это солнце, но лишь оно греет все, что ныне дрожит, скованное морозом и ложью (европейских) тиранов. < ...> Печально для русской эмиграции, которая тоже часть нашего общества, то, что один из её членов, русский писатель, настолько возненавидел Ленина, что забыл то, что он русский. И стал европейцем, и стал прославлять того, кто в 1812 году напал на его родину».

Описывая картины «беженской России», как он её называет и которая начинает складываться в это время, Николаевич, чутко понимает её слабости и её силу. Он даёт картины её униженности, её беспомощного состояния, её отчуж- 
дённости от матрицы. Один из героев пьесы - Азиат, говорит, что «...беженская Россия - это та Россия, которая думает и чувствует, чувствует глубоко и хаотично, страдает и трудится от зари до темна. Это та Россия, чью духовную и физическую силу так подло используют европейцы. И она, та, которая пролагает путь всему, идёт с покорно опущенной стыдливо головой, и её сыновья - вечные швейцары у чужих подъездов, извиняющиеся даже за то, что своими могилами они заняли кусок чужой земли - это и есть беженская Россия!» Описывая униженную и оскорбленную «беженскую Россию» Николаевич пророчествует: «Но просуществует она недолго: или растворится в Европе, или погибнет в угаре. Нет для русских жизни без Отечества!»

Интересно, что уже в 1926 году Николаевич фиксирует то, что потом назовут - Зарубежной Россией. Фиксирует, что сложилось определённое культурное явление, которое обладает целостностью; явление, которое породило свой культурный тип и включило его в модель того мира, где он вынужден был жить и в который вынужден был интегрироваться. Фиксируя наличие «беженской России», он видит и слабости этого образования, его кратковременность и рыхлость. В окончании пьесы звучат слова: «Мне жаль всех беженцев русских. Жалею их, поскольку вернуться не хотят. Несчастные они.». Применение двух Россий - это та сила, на которую надеется весь славянский мир и которой боится Европа. Именно эту идею и пытается показать в своей пьесе Душан Николаевич, причём использует как традиционные драматургические приёмы, так и включает в пьесу элементы притчи и даже воззвания или прокламации.

Проблему «слезинки ребенка» во имя будущего блага Душан Николаевич решает, описывая ситуацию, в которой русский эмигрант Андрей Денисов совершает покушение на представителя советского государства (в пьесе он просто назван товарищем). Это одна из последних сцен в пьесе, которая написана, вероятнее всего, под впечатлением от убийства Петра Войкова, которое совершил русский эмигрант Борис Коверда: 7 июня 1927 года Борис Коверда на железнодорожном вокзале в Варшаве открыл огонь по советскому полномочному представителю в Польше Петру Воейкову. Пьеса же поступила на прилавки магазинов в начале сентября 1927 года. По мнению Николаевича, убийство - храбрый поступок, но это тупиковый ход. Две России должны найти путь примирения. И понять друг друга они могут лишь, помирив Достоевского и Ленина: в пьесе в знак примирения Достоевский целует руку Ленина. Сам автор в интервью газете «Правда» от 19.10. 1934 года о своей драме говорил как о модели, которая позволяет исследовать столкновение «азиатско-византийской» России с Россией «большевистской», с гордостью подчёркивая, что мнение Мориса Палеолога о Ленине и Достоевском лишь бледный слепок его идей.

Конечно, к данному эпатажному высказыванию автора можно отнестись пренебрежительно, но факт, что в сербской прессе дискуссии о мистической роли Ленина и о его близости (несмотря на все различие) с исконным русским миром, представленным Достоевским, начались задолго до лекций М. Палеолога на эту тему (газета «Время», 23.12.1937).

Споры о русской эмиграции, споры о Ленине и революции в России неизменно приводят к дискуссии о Достоевском: «Через Достоевского и только через Достоевского мы поймём Ленина», - говорит Николаевич, чья неорди- 
нарная пьеса, как мы уже писали, заканчивается сценой, где есть и волжский разлив, который потопом грозит уничтожить Европу, и распятый Лениным Достоевский, целующий ему руку, и Ленин, осеняющий себя крестом.

Интересно, что идеи Николаевича частью войдут в книгу русского эмигранта Николая Николаевича Чухнова (1897-1978), который в то время был председателем Союза российской молодёжи в Югославии, а также главным редактором еженедельника «Словен», который издавался в Белграде. Книга Чухнова под названием «Расплата» вышла с подзаголовком - эмигрантское движение, в 1931 году в Бибиотеке Института изучения России и имела предисловие Николая Рклицкого (1892-1976), будущего архиепископа Вашингтонского и Флоридского Никона, в то время редактора газеты «Царский Вестник». Герои повести Чухнова также спорят о путях примирения и также прибегают к Достоевскому как к последнему аргументу. Также как и Николаевич, Чухнов подтолкнёт своих героев к теории индивидуального террора, хотя в своих оценках не будет столь категоричен, как Николаевич, поскольку считает, что для того, чтобы убить бесов, нужно самим быть бесом (Чухнов 1931).

Впрочем, сама русская эмиграция тоже воспринимала себя через призму Достоевского, и в русской эмигрантской прессе также много споров в которых проблема выживания в чужой среде сопряжена с проблемами национальной идентификации и противления Европе, а Балканы представлены как территория возможного собирания славянского мира. Об этом писали и митрополит Киевский и Галицкий Антоний Храповицкий - первый председатель Архиерейского синода Русской православной церкви за границей, и Никон (Николай) Рклицкий, о котором мы уже упомянули и, Александр Погодин, автор серии публицистических текстов о Достоевском, и др. Анализ таких газетных текстов также может быть очень интересным не только как часть науки исследований о творчестве Достоевского, но и как возможность понять те проблемы, которые волновали нашу эмиграцию.

Упомянутая теория примирения с Советской Россией, т.е споры так называемых «оборонцев» и «пораженцев» - очень чувствительная тема, особенно здесь на Балканах, которая приводила к дискуссиям, спорам, скандалам и даже дракам (знаменитый диспут в Русском доме в Белграде, который был связан с событиями на КВЖД и угрозами СССР со стороны Японии. Основной доклад делал П.Б. Струве, занимавший пораженческие позиции и призывавший эмиграцию быть вместе с Японией. Илья Толстой же, горячо защищая оборонческие позиции, заявлял, что эмиграция, во всяком случае молодая, не будет на стороне врагов России. Речь Толстого с едкими пассажами в адрес Струве и Милюкова настолько наэлектризовала аудиторию, где присутствовало много пораженцев, что Толстого забросали помидорами!. ( «Бух!» 1929)

«Пораженцы», ненавидя Советскую Россию считали, что спасение России в интервенции. «Оборонцы» же считали, что возможен путь примирения, некая «союзная империя», которая сможет объединить и «царя и Советы». Самыми яркими представителями этой идеологии было движение «Союз младороссов», которые выдвинули лозунг «Ни белые, ни красные, но русские», который вполне совпадает и с идеей пьесы Душана Николаевича. 
Драма Душана Николаевича вызвала большой интерес не только в Сербии: о ней отдельно писал известный достоевист А. Л. Бем, чье мнение охотно печатают сербские газеты, а по анонсам газет, пьесу на русский собирался переводить А.И. Куприн (газета «Время», 1929 от 27.08). А то, что название «Волга, Волга!» совпадало с вышедшим в 1929 году фильмом режиссёра Туржанского в немецкой продукции, только увеличило популярность (советский фильм «Волга-Волга» режиссера Г. Александрова вышел на экраны только в 1938, а в Королевстве Югославия шёл с двойным названием - как фильм «Волга, Волга», и как «Пастух Костя»).

Долгое время пьеса распространялась или в печатном виде (во многом она и подразумевалась как пьеса для чтения: слишком много монологов, вставок, неудобных для сцены переходов и пр.) или её играли на сценах частных театров. Но её популярность и сетования автора в газетных интервью, что лучшая его пьеса не поставлена на «большой сцене», привели к кому, что большая сцена Национального театра была ему представлена.

Премьера состоялась 23 ноября 1935 года. Режиссёром был Радослав Веснич, а сценографом Станислав Беложански. Федора Михайловича Достоевского играл популярный актёр Фран Новакович, а Ленина, который назван в программе Антидостоевский - актер Светолик Никачевич.

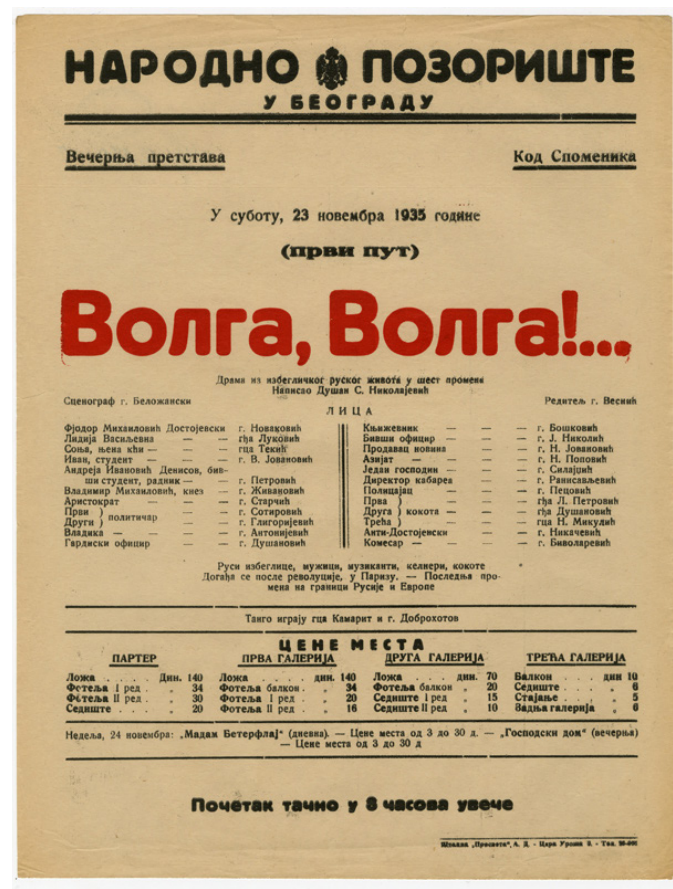

Плакат пьесы «Волга Волга!», Архив Музея театрального искусства в Белграде, ИД: 124927, Инвентарный номер: 12170-7 
О популярности пьесы свидетельствует то, что пьеса продержалась на сцене Национального театра почти два года и то, что она вызвала споры, дискуссии и даже карикатуры.

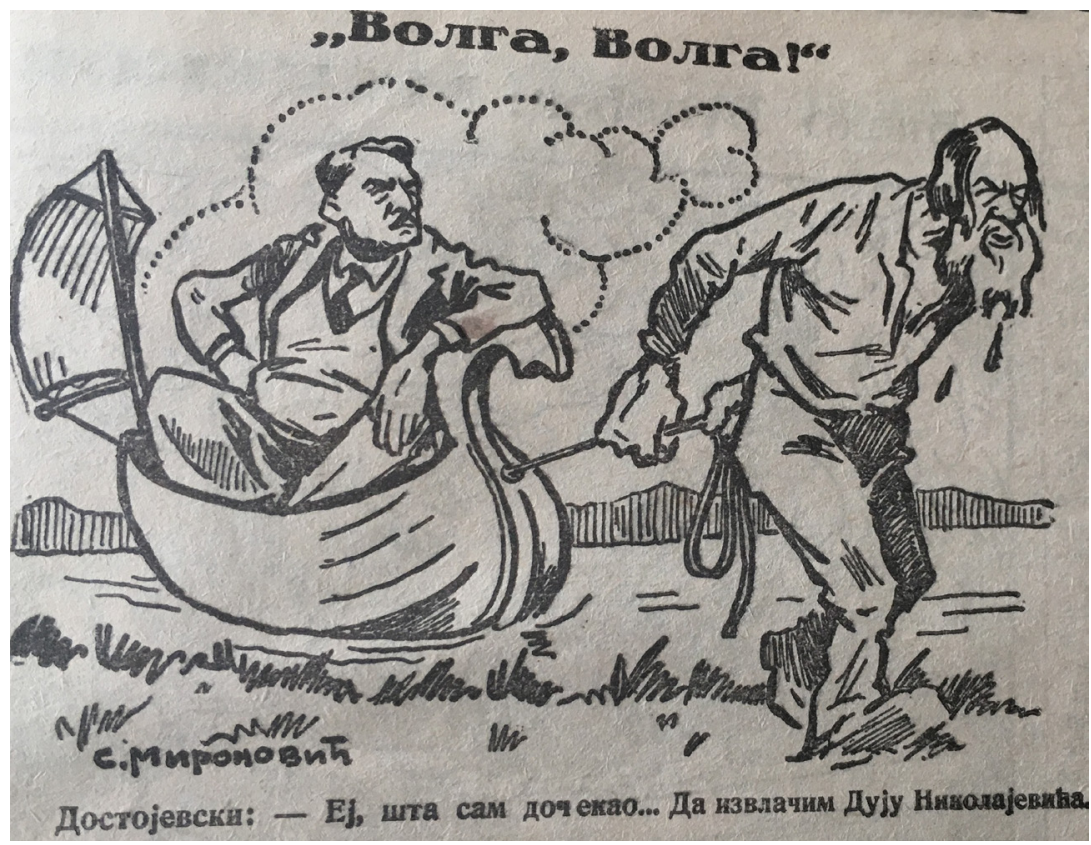

Карикатура известного художника, также русского эмигранта, Сергея Головченко (под псевдонимом Миронович) в газете «Стриженный еж» (Ошишани јеж) за 1935 год под названием «Волга, Волга!», где в виде бурлака ворчит: «Эх, вот до чего дожил... - вытаскиваю Дуду (сокращённый вариант имени Душан) Николаевича».

Это интерес связан и со спорами внутри самого сербского общества, которое тоже, как и русские, стояло перед выбором национального или югославского пути развития, ставшим наиболее острым после убийства короля Александра Первого Карагеоргиевича в Марселе в 1934 году. И эти споры обязательно нужно рассматривать и в этом контексте, который, конечно же, выходит за рамки этой статьи, но о котором, несомненно, следует упомянуть, Как мы видим, споры о Достоевском, которые появляются на страницах печати, могут дать исследователю возможность посредством анализа понять и какие проблемы волновали как русскую эмиграцию, которая, формируясь в системных рамках Зарубежной России, решала важные для себя проблемы, так и сербское общество, которое также своё восприятие России и русских беженцев на Балканах пропускало через призму идей, заложенных в творчестве Достоевского. Нам кажется, перспективы подобных исследований могут обогатить как науку о русской эмиграции, так и добавить некоторые новые имена в достоевсковедение. 


\section{Использованная литература}

Богдановић, Милан. „Душан Николајевић (Многаја љета, Парола, Преко мртвих, Вечна копрена)”. [У:] Драма, Српска књижевност у књижевној критици. Београд, 1973, 334-351.

[Bogdanovic Milan. „Dusan Nikolajevic, Mnogaja leta, Parola, Preko mrtvih, Vecna koprena)". [U:] Drama, Srpska knjizevnost u knjizevnoj kritici. Beograd, 1973, 334 351]

Јордановић, Бранислава, Маја Николова, Милена Марковић. Ректори Лицеја, Велике школе и Универзитета у Београду: 1838-2005. Београд: Славистичко друштво Србије, 2005, 52-53.

[Jordanović Branislava, Maja Nikolova, Milena Marković. Rektori Liceja, Velike škole i Univerziteta u Beolgradu: 1838-2005. Beograd: Slavističko društvo Srbije, 2005, 52-53]

Марић, Андреја. „Три драмска писца: идејне и поетичке сродности и разлике”. Филолог VI, 2012: 110-124.

[Marić, Andreja. „Tri dramska pisca: idejne i poetičke srodnosti i razlike”. Filolog VI, 2012: 110-124]

Марић, Андреја. „Породичне и љубавне интриге у друштвено-критичким драмама Душана С. Николајевића”. [У:] Зборник Од науке до наставе: тематски зборник радова. Наука и савремени универзитет. Ниш, 2013, 305-315.

[Marić, Andreja. „Porodicne i ljubavne intreige u društveno-kritičkim dramama Dušana S.Nikolajevića". [U:] Zbornik Od nauke do nastave:tematski zbornik radova. Nauka i savremeni univerzitet. Niš, 2013, 305-315]

Успенски, Ениса. «Достоевский и достоевсковедение, как диалог русской эмиграции с югославской культурой между двумя войнами». [В:] Русское зарубежье и славянский мир. Београд, 2013, 559-577.

[Uspenski, Enisa. „Dostojevski i dovstojevskovedenie kak dialog russkoj emigracii s jugoslavskoj kuljturoj meždu dvumja vojnami”. [V:] Ruskoje zarubežje i slavjanskij mir. Beograd: 2013, 559-577]

Gligorić, Velibor. „Dušan S. Nikolajević - Parola”. [U:] Biće pozorišta. Novi Sad: Sterijino pozorje, 1977b, 71-73.

Vučković, Radovan. Moderna drama. Sarajevo: IRO „Veselin Masleša”, 1982.

\section{Источники}

Николајевић, Душан С. Волга, Волга !..: драма из избегличког руског живота : шест промена, Београд: Француско-српска књижара А. М. Поповића, 1927.

[Nikolajevic, Dusan S. Volga, Volga!... drama iz izbeglickog ruskog zivota: sest promena. Beograd: Francusko-srpska knjizara A. M. Popovica, 1927]

Чухновь, Николай Николаевичъ. Расплата : (эмигрантское дъствіе) / сь предисловіем Ник. Рклицкаго. Белградь: Библіотека Института изученія Россіи [б. и.], 1931.

[Cuhnov, Nikolaj Nikolajevic. Rasplata: (emigrantskoe dejstvije)/ s predislovijem Nik. Rkslickog. Belgrad: Biblioteka izucenija Rossii [b. i.], 1931] 


\section{Ирина Антанасијевић}

\section{ДРАМА ДУШАНА С. НИКОЛАЕВИЧА „ВОЛГА, ВОЛГА!“ У КОНТЕКСТУ ДИСКУСИЈА О РУСКОЈ ЕМИГРАЦИЈИ}

\section{Резиме}

У чланку се анализира драма писца Душана С. Николајевича „Волга, Волга!“ (1927), чије истраживање може пружити јаснију слику рецепције руске емиграције у српском друштву, које је руску емиграцију разматрало кроз призму идеја Достојевског. Анализа драме Душана Николајевича „Волга, Волга! Драма из живота руских избеглица“ показује да као у руска емиграција, која у стваралаштву Достојевског тражи одговоре на питања националног идентитета, тако и српско друштво, руску емиграцију посматрају у склопу тих тема којима се бавио писац.

Кључне речи: руска емиграција, Достојевски, Душан С. Николајевич, „Волга, Волга!“. 